\title{
Abraham Skorka \\ Leadership Talk by the Rector of the Seminario Rabínico Latinoamericano Buenos Aires
}

The first thoughts and sentiments that came into my mind and heart when I had received the proposed theme of this panel was about the terrible silence which accompanies us Jews throughout the greater part of our history-both heavenly silence and human silence. Jews have had many opportunities to understand, since the very beginning of their existence, the meaning of suffering, such as they experienced during the slavery in Egypt. They questioned God about the suffering of the people and especially about the unjust suffering of the righteous. Jeremiah (Jer 12:1-5) ${ }^{1}$ posed the question and received an answer similar to the one God gave to Job: "Who are you, O mortal, that I should reveal my secrets to you?" When the Talmudic sages asked desperately why their colleagues were being tortured to death by Hadrian's legionaries, the answer they received from God, from Heaven was: "Keep silent!" 2 These were my initial reflections about the theme of this panel.

In 1944, when the dimensions of the Shoah began to be known among Jews living outside of Europe, Yehudah Leib Magnes, then president of the Hebrew University of Jerusalem, in the opening address for its twentieth academic year, quoted Rabbi Levi Yitzhak of Berdichev's dramatic question: "I do not ask, Lord of the World [...] to know why I suffer, but only this: Do I suffer for Thy sake?"3

André Neher investigated this issue for years and wrote a masterpiece: The Exile of the Word: From the Silence of the Bible to the Silence of Auschwitz. ${ }^{4}$

However, it is not the silence of God toward Jewish suffering that we come to analyze today but the human silence and indifference towards the plight of their Jewish brothers and sisters. My father used to be a great reader of Yiddish liter-

1 In accordance to Radak's exegesis.

2 Bavli Menahot 29b.

3 J. L. Magnes, "For Thy Sake Are We Killed All the Day Long!" Opening address, $20^{\text {th }}$ academic year, Hebrew University, issued November 1, 1944, in The Perplexity of Times, ed. J. L. Magnes (Jerusalem: Hebrew University Press, 1946), 65-78.

4 Cf. A. Neher, The Exile of the Word. From the Silence of the Bible to the Silence of Auschwitz (Philadelphia: Jewish Publication Society of America, 1981; originally published in France under the title L'Exil de la Parole, Paris: Éditions du Seuil, 1970).

๑ OpenAccess. () 2019 Abraham Skorka, published by De Gruyter. (cc) BY-NC-ND This work is licensed under the Creative Commons Attribution-NonCommercial-NoDerivatives 4.0 License. 
ature, and from time to time he read and shared with me things that made an impact on him, even though I was then just a little boy. The books he read were published in Argentina and one of them was Un di Velt Hot Geshvigen ${ }^{5}$ [And the World was Silent] by Elie Wiesel. A shortened French version of the book became his famous novella La Nuit [The Night], when the Noble prize winner François Mauriac encouraged him to publish it. That was my first encounter with human silence regarding the saga of the Jews.

A second pivotal experience for me of this silence I felt personally in the weeks before the Six-Day War in 1967. The impressive victory of the Israeli Defense Forces concealed the anguish and anxiety suffered by Jews in Israel and throughout the world. The Israeli Prime Minister, the Foreign Affairs Minister, and even the old President were seen on television screens calling, begging for a peaceful solution. Gamal Abdel Nasser, the Egyptian president, declared constantly that his ultimate aim was to throw all the Jews living in Israel into the Mediterranean. Since that day, we know the outcome of his efforts, so it is easy to forget the anguish felt then. But at the time, I asked myself, I asked God: "Are Hitler's survivors going to be annihilated? Will what Hitler did not finish be completed by Nasser and his allies?”

The United Nations were totally unable to resolve the crisis peacefully. The self-interests of the rival Cold War superpowers dictated the speeches of the representatives of the great powers. They played a political chess match at a safe distance while real people were preparing to fight and die in their proxy war. The Jews of Israel stood alone again, in silence, as in Europe twenty-seven years earlier.

Elie Wiesel masterfully bound these two anguishes and silences in the first paragraphs in his book A Beggar in Jerusalem. ${ }^{6}$

Silence and indifference in the face of antisemitic acts and words was-and continues to be-a great failing of many institutions at large and of religious organizations in particular. One of the strongest weapons that antisemites have in their hands is the indifference of the others. A careful reading of the history of the Shoah reveals that Hitler only determined his "final solution" of the Jewish problem-their total physical extermination-on January 30, 1942, when the Wannsee conference took place. This was years after the Shoah is usually considered to have begun on November 10, 1938; Hitler came to his abominable reso-

5 Cf. E. Wiesel, Un di Velt Hot Geshvigen (Buenos Aires: Tsentral Verband fun Poilishe Yiden in Argentine, 1956).

6 Cf. E. Wiesel, Le mendiant de Jérusalem (Paris: Éditions du Seuil, 1968). 
lution only after seeing the silence and apathy that his antisemitic policies had produced to that point.

In addition, in some Christian denominations and in some language coming from the Islamic world, there still persists a theological antisemitism. One of the most sincere and meaningful self-criticisms on this subject can be found in Cardinal Walter Kasper's foreword for the book: Christ Jesus and the Jewish People Today:

The history of Jewish-Christian relations is complex and difficult. In addition to some better times, as when bishops took Jews under their protection against pogroms by mobs, there were dark times that have been especially impressed upon the collective Jewish consciousness. The Shoah, the state sponsored organized murder of approximately six million European Jews, based on primitive racial ideology, is the absolute low point in this history. The Holocaust cannot be attributed to Christianity as such, since it also had clear anti-Christian features. However, centuries-old Christian theological anti-Judaism contributed as well, encouraging a widespread antipathy for Jews, so that ideologically and racially motivated anti-Semitism could prevail in this terrible way, and resistance against the outrageous inhuman brutality did not achieve the breadth and clarity that one should have expected.

Unfortunately, it required the unprecedented crime of the Shoah for a fundamental rethinking to come about. ${ }^{7}$

In our present reality, antisemitism is one of a large number of fanatical violent expressions that hurts humanity. In his visit to the Al-Azhar University in Egypt, Pope Francis and Professor Ahmed El-Tayyeb, Grand Imam of Al-Azhar, condemned in the strongest terms all those who kill and teach hate in the name of God. When such abhorrent things occur, the voices of all the religious leaders are not as loud and clear as they must be. Universal and unified verbal religious condemnation is a powerful force against antisemitism and all kinds of racism. Instead, cynical comments and attitudes are very often what appear in the world media. Human blood has the same color and characteristics for everyone. It does not matter if it is Jewish blood, Christian blood, or Muslim blood. When one person is killed by the madness of bigotry, humankind has to be in mourning.

Antisemitism is a very difficult phenomenon to understand. Jean-Paul Sartre, ${ }^{8}$ Hannah Arendt, ${ }^{9}$ and many other brilliant minds devoted their best intellectual powers to uncover its roots and motivations. In our day, antisemitism

7 W. Kasper, foreword to Christ Jesus and the Jewish People Today, ed. P. A. Cunningham et al. (Rome: Gregorian \& Biblical Press, 2011), $\mathrm{x}$-xi.

8 Cf. J. P. Sartre, Réflexions sur la question juive (Paris: Éditions Morihien, 1946).

9 Cf. H. Arendt, The Origins of Totalitarianism (New York: Harcourt, 1951). 
also can be expressed as an anti-Zionism that desires to see the end of the existence of the State of Israel.

Zionism is rooted in the two thousand years hope of the Jewish people of returning to the land of Israel. Isaiah's and Ezekiel's prophecies were not understood by many Jews throughout the generations as merely a fantasy or a metaphor but as a reality that could come into being. Jews prayed and continue praying each day for the reunification of their people in Zion, and the return of God's presence to it. The land, and today the State of Israel, is a defining aspect of Jewish spiritual identity.

Hasidim and Mitnagdim, the two great Jewish religious movements in the eighteenth century organized alyiot, the establishment of members of their communities in different cities of what was then a province of the Turkish Empire. After the last decades of the nineteenth century, Jews that looked for a new style of Judaism, with religious values expressed in different ways, came to the land and transformed swamps into oases. Hebrew was transformed into a living language, and many other cultural aspects of Judaism were revitalized.

When David ben Gurion visited Argentina in 1969, he delivered a message to the Jewish community of Buenos Aires. He summarized the history and achievements of the Zionist movement, and concluded by rephrasing the verse of Psalm 29:11, which says: "The Lord will give strength to his people; the Lord will bless his people with peace," into: "The Lord gave strength to his people; the Lord will bless his people with peace." Most of the dreams of the Zionists became a reality in a democratic modern state, living in peace with its neighbors. The greatest contribution that the various religions can offer to Jews nowadays is to proclaim messages and spread attitudes of peace that lead to the solution of the IsraeliPalestinian controversy. To express clearly in all possible ways, through every type of media, that terror is not the way, that war is not a solution. They must insist that the life and future of each Israeli and Palestinian youngster, whether Jew, Christian, or Muslim, must be everyone's primary concern, and that dialogue is the only tool to pave the way to this future.

Jewish history as conveyed by Jewish liturgy recalls that each generation has known a poisonous leader who tried to eliminate the Jewish people: Pharaoh, Amalek, Haman from Susa, Titus, Hadrian, Inquisitions, Pogroms, etc. In the words of the traditional Haggadah that Jews recite during the Passover dinner: "For not just one person alone has risen against us to destroy us, but in every generation they rise against us to destroy us; and the Holy One, blessed be He, saves us from their hands!" It is a challenge for all of us, and especially for religious leaders, to make in our generation a turning point in history, to change inherited hatred into friendship. This will enable us to realize that 
dream of human unity that all religions have sought since they first discovered the presence of God in the midst of human reality.

Rabbi Dr. Abraham Skorka was ordained a rabbi by the Seminario Rabínico Latinoamericano, earned a Ph.D. in Chemistry from the Universidad de Buenos Aires, and served as Rector of the Seminario Rabínico Latinoamericano and as Rabbi of the Benei Tikva Congregation in Buenos Aires. He has received honorary doctorates from the Pontificia Universidad Católica Argentina, The Jewish Theological Seminary, and Sacred Heart University. Rabbi Skorka has published many articles on topics in biophysics, biblical and Talmudic studies, and interreligious relations. $\mathrm{He}$ is the author of several books, including On Heaven and Earth, co-authored with the then archbishop of Buenos Aires, Cardinal Jorge Mario Bergoglio, the current Pope Francis. He is currently a visiting University Professor at the Institute for Jewish-Christian Relations of Saint Joseph's University, Philadelphia.

\section{Bibliography}

Arendt, Hannah. The Origins of Totalitarianism. New York: Harcourt, 1951.

Kasper, Walter. Foreword to Christ Jesus and the Jewish People Today, edited by Philip A. Cunningham et al. Rome: Gregorian \& Biblical Press, 2011.

Magnes, Jehuda Leib. "For Thy Sake Are We Killed All the Day Long!” Opening address, $20^{\text {th }}$ academic year, Hebrew University, issued November 1, 1944. In The Perplexity of Times, edited by Jehuda Leib Magnes, 65-78. Jerusalem: Hebrew University Press, 1946.

Neher, André. The Exile of the Word: From the Silence of the Bible to the Silence of Auschwitz. Philadelphia: Jewish Publication Society of America, 1981.

Sartre, Jean Paul. Réflexions sur la question juive. Paris: Éditions Morihien, 1946.

Wiesel, Elie. און די וועלט האָט געשרוויגן פון פוילישע יידן אין ארגענטינע [Tsentral Verband fun Poilishe Yiden in Argentine], 1956.

Wiesel, Elie. Le mendiant de Jérusalem. Paris: Éditions du Seuil, 1968. 
